\title{
Upaya Menjaga Kebugaran Jasmani Dan Kesehatan Melalui Koreografi Senam Imaji Pandemi Pada Siswa MIM Delegtukang
}

\author{
Yustiana Nabila ${ }^{*}$, Helmi Fatinabila ${ }^{2}$, Imroautul Maghfiroh ${ }^{3}$, Yusril Ihza \\ Mualana ${ }^{4}$, Gilang Nuari Panggraita ${ }^{5}$ \\ 1,2,3,4,5 Program Studi Pendidikan Jasmani, Universitas Muhammadiyah Pekajangan Pekalongan, \\ Indonesia \\ *email: nabilayustianai@gmail.com
}

\begin{abstract}
This training activity aims to provide health sports program training for the maintenance of physical fitness of students at the madrasah level during the covid-19 pandemic. The substance of this devotional activity includes; education on the importance of maintaining physical fitness during pandemics, mentoring physical fitness practice, and education on the principles of good and correct physical fitness training include; Form of exercise, objectives and targets of exercise. Students / $\mathrm{i}$ who are the target of this devotional activity are students / i level Madrasah Ibtidaiyah Delegtukang, Wiradesa Subdistrict, Pekalongan Regency.. This devotional activity is carried out using a lecture approach and direct practice assistance by the service team. The result of this devotional activity is (1) students / i have a good understanding of the importance of maintaining physical fitness, (2) mastering physical exercise skills for the maintenance of physical fitness during the covid-19 pandemic, and (3) have an understanding of the principles of good and correct physical fitness training including; Form of exercise, objectives and targets of exercise.
\end{abstract}

Keywords: Physical Fitness And Health, Choreographed Activities, Pandemic Imaji Gymnastics

\begin{abstract}
Abstrak
Kegiatan pelatihan ini bertujuan untuk memberikan pelatihan program olahraga kesehatan untuk pemeliharaan kebugaran jasmani siswa/i tingkat madrasah di masa pandemi covid- 19 . Substansi kegiatan pengabdian ini meliputi; edukasi pentingnya pemeliharaan kebugaran jasmani selama masa pandemi, pendampingan praktik latihan kebugaran jasmani, serta edukasi mengenai prinsip-prinsip latihan kebugaran jasmani yang baik dan benar meliputi; bentuk latihan, tujuan dan sasaran latihan. Siswa/i yang menjadi target kegiatan pengabdian ini adalah siswa/i tingkat Madrasah Ibtidaiyah Delegtukang, Kecamatan Wiradesa, Kabupaten Pekalongan. Kegiatan pengabdian ini dilakasanakan dengan menggunakan pendekatan ceramah dan pendampingan praktik secara langsung oleh tim pengabdi. Hasil dari kegiatan pengabdian ini adalah (1) siswa/i memiliki pemahaman yang baik mengenai pentingnya pemeliharaan kebugaran jasmani, (2) menguasai keterampilan latihan fisik untuk pemeliharaan kebugaran jasmani selama pandemi covid-19, serta (3) memiliki pemahaman mengenai prinsip-prinsip latihan kebugaran jasmani yang baik dan benar meliputi; bentuk latihan, tujuan dan sasaran latihan.
\end{abstract}

Kata kunci: Kebugaran Jasmani Dan Kesehatan, Aktivitas Koreografi, Senam Imaji Pandemi

\section{Pendahuluan}

Kebugaran jasmani merupakan faktor utama yang mempengaruhi status kesehatan setiap individu [11]. Secara sederhana, kebugaran jasmani dapat dipahami sebagai kemampuan seseorang dalam melakukan suatu tugas gerak tertentu secara maksimal dan efisien tanpa mengalami kelelahan yang berlebihan serta terhindar dari resiko gangguan kesehatan [3]. 


\section{Prosiding Seminar Nasional Kesehatan Lembaga Penelitian dan Pengabdian Masyarakat Universitas Muhammadiyah Pekajangan Pekalongan}

Kebugaran jasmani juga merupakan bagian yang penting dalam kehidupan seharihari yang menunjukkan kualitas hidup sehat secara paripurna. Pada hakikatnya kebugaran jasmani merupakan derajat kualitas seseorang untuk bisa beraktivitas secara optimal tanpa mengalami masalah kesehatan serta kelelahan yang berlebihan sesuai dengan tugas atau profesinya masing-masing [12]. Berbagai kegiatan seperti belajar, bekerja, berolaharga, maupuan kegiatan-kegiatan yang dilakukan pada masa senggang memerlukan kebugaran yang baik.

Pendidikan jasmani sebagai mata pelajaran yang mengembangkan Pendidikan jasmani olahraga dan kesehatan merupakan bagian integral dari pendidikan secara keseluruhan yang bertujuan untuk mengembangkan aspek kebugaran jasmani, keterampilan gerak, keterampilan berpikir kritis, keterampilan sosial, penalaran, stabilitas emosional, tindakan moral, aspek pola hidup sehat, dan pengenalan lingkungan bersih melalui aktivitas jasmani, olahraga dan kesehatan terpilih yang direncanakan secara sistematis dalam rangka mencapai tujuan pendidikan nasional. Pada intinya pembelajaran dalam pendidikan jasmani berusaha mengembangkan kemampuan peserta didik secara holistik baik dari segi fisik, mental maupun emosional melalui kegiatan aktivitas fisik.

Pendidikan jasmani pada dasarnya merupakan satu kesatuan sistem dalam pendidikan secara keseluruhan, yaitu untuk mengembangkan berbagai aspek salah satunya adalah kebugaran jasmani. Sebagai bagian dari program pendidikan jasmani di sekolah, pembinaan kebugaran jasmani sangat strategis, karena mendukung kapasitas belajar bagi siswa dan menggiatkan pertisipasi siswa secara menyeluruh [1], dengan meningkatkan dan memelihara kebugaran jasmani pada semua kalangan, dimulai sedini mungkin dari tingkat anak-anak.

Kesadaran akan pentingnya melakukan olahraga secara rutin, mengkonsumsi makan bergizi dan istirahat yang cukup semakin dipahami, apalagi di masa pandemi covid-19 yang sedang melanda di seluruh dunia. Maka perlu diupayakan sebagai bagian penerapan hidup sehat yang perlu dikembangkan di masyarakat luas. Karena kebugaran jasmani menjadi dasar pemeliharaan kesehatan, produktivitas kerja, bahkan peningkatan prestasi.

Selama masa pandemi COVID-19, usaha pemeliharaan kebugaran jasmani perlu untuk tetap dilakukan sebagai salah satu tindakan preventif dalam rangka meningkatkan imunitas tubuh secara khusus serta pemeliharaan kesehatan secara umum [4]. Tidak dapat dipungkiri bahwa resiko penerapan belajar dari rumah selama pandemi COVID-19 telah banyak berdampak pada kurangnya intensitas aktivitas fisik pelajar pada umumnya.

Pandemi covid-19 telah membawa perubahan besar di berbagai bidang termasuk bidang pendidikan. Pemberlakuan Kebijakan Belajar Dari Rumah (BDR) telah berlangsung kurang lebih 2 tahun sejak terjadinya pandemic covid-19. Semua aktivitas pembelajar siswa dilakukan secara daring di rumah masing-masing. Hal ini dilakukan untuk menekan laju penyebaran virus covid-19 yang belum menunjukan perubahan signifikan terhadap penurunan jumlah kasus di Indonesia. Akan tetapi, pemberlakuan kebijakan ini memiliki dampak yang kurang baik dari segi aktivitas fisik siswa.

Penelitian menunjukkan bahwa kelompok siswa yang sekolah normal kebugaran jasmaninya lebih baik dari pada kelompok siswa yang sekolah daring. Apabila hal 


\section{Prosiding Seminar Nasional Kesehatan Lembaga Penelitian dan Pengabdian Masyarakat Universitas Muhammadiyah Pekajangan Pekalongan}

tersebut terus menerus berlangsung maka akan menyebabkan tubuh manusia menjadi lemah kemudian diikuti dengan penurunan daya tahan tubuh, sehingga mudah terserang suatu penyakit yang akan mengakibatkan kondisi rentan terserang virus COVID19 [8]. Ditambah lagi dengan persoalan kurangnya katifitas fisik yang semakin meluas dengan lebiih dari $30 \%$ seseorang gagal dalam memenuhi tungkat aktivitas fisik yang memdahi [2]. Oleh karena itu, perlu adanya pencegahan sedini mungkin dengan adanya program yang secara rutin yang dapat dilaksanakan secara sistematis dan berkelanjutan [5].

Upaya memerangi penyebaran dan penularan COVID-19, lembaga pendidikan tinggi melalui program tri dharma, perlu melakukan usaha konkret untukmembantu meminimalisir resiko gangguan kesehatan sebagai dampak pandemi COVID-19 di kalangan pelajar. Usaha pemeliharaan kebugaran jasmani mahasiswa melalui program latihan olahraga mandiri di rumah dapat menjadi solusi praktis yang bermanfaat untuk pemeliharaan kondisi fisik. Pemeliharaan kondisi fisik hanya bisa dilakukan dengan membiasakan pola hidup aktif melalui aktivitas latihan atau olahraga. Program olahraga mandiri di masa pandemi COVID-19 perlu diarahkan pada tujuan untuk pemeliharaan kebugaran jasmani yang berkaitan dengan kesehatan (health related physical fitness) [3].

Komponen utama yang harus menjadi sasaran latihan kebugaran adalah kesehatan kardiovaskular, kekuatan dan daya tahan otot serta kelentukan. Merujuk pada pengaruh serangan virus COVID-19 yang dapat melemahkan sistim imun tubuh maka dipandang perlu untuk melakukan upaya pemeliharaan dan peningkatan imunitas tubuh melalui latihan fisik yang adekuat agar menjaga kekuatan dan daya tahan tubuh tetap dalam kondisi optimal [14]. Selain menunjang pemeliharaan kebugaran jasmani, latihan fisik yang adekuat juga berkontribusi penting dalam kinerja kognitif seseorang [6]. Untuk itu, usaha pemeliharaan kebugaran jasmani melalui aktivitas latihan fisik, perlu dilakukan secara teratur dan berkesinambungan sehingga dapat memberikan manfaat jangka panjang yang lebih maksimal.

Latihan kebugaran dapat dilakukan dengan berbagai cara, salah satunya melalui aktivitas koreografi senam imaji. Aktivitas senam koreografi merupakan salah satu bentuk latihan fisik dengan memanfaatkan tubuh sendiri. Pendekatan senam koreografi mempunyai tujuan untuk melatih aspek daya tahan kardiovaskuler, daya tahan otot, kelentukan, serta memperbaiki kondisi kebugaran fisik secara umum [14]. Sedangkan senam imaji merupakan salah satu bentuk pengembangan aktivitas senam koreografi Universitas Muhammadiyah Pekajangan Pekalongan yang merefleksikan gerakan 3M (Mencuci tangan, Memakai Masker, Menjaga jarak) sebagai suatu gerakan yang perlu diterapkan selama pandemi. Selain itu gerakan senam ini mengadaptasi gerakangerakan wudhu, sholat dan juga jenis olahraga yang terdapat didalam Al-Qur'an (Renang, Berkuda dan Memanah) serta gerakan Tapak Suci.

Secara praktis, aktivitas koreografi senam imaji pandemi sangat relevan untuk dilakukan selama masa pandemi COVID-19 karena dapat dilakukan secara mandiri di rumah, tidak membutuhkan fasilitas latihan yang mahal, durasi latihan relatif lebih singkat dengan sasaran kelompok otot yang dilatih lebih banyak, serta tidak memiliki resiko mengalami cedera yang berarti selama latihan, serta lebih mudah diarahkan untuk melatih beberapa komponen kebugaran jasmani, yang menyangkut dengan 


\section{Prosiding Seminar Nasional Kesehatan Lembaga Penelitian dan Pengabdian Masyarakat Universitas Muhammadiyah Pekajangan Pekalongan

kesehatan (health related physical fitness) yang meliputi komponen daya tahan kardiovaskuler, daya tahan otot, kelentukan serta komposisi tubuh [3].

Merujuk pada berbagai hal yang berkaitan dengan kondisi penyebaran covid-19, maka kegiatan pengabdian kepada masyarakat ini berfokus pada beberapa hal penting yang meliputi; (1) peningkatan pemahaman siswa/i tingkat madrasah mengenai pentingnya pemeliharaan kebugaran jasmani di masa pandemi covid-19, (2) penguasaan keterampilan fisik untuk pemeliharaan kebugaran jasmani siswa/i tingkat madrasah di masa pandemi COVID-19, (3) peningkatan pemahaman siswa/i tingkat madrasah tentang prinsip-prinsip dasar program latihan kebugaran jasmani yang baik dan benar meliputi; bentuk latihan, tujuan dan sasaran latihan, intensitas latihan, frekuensi latihan, serta durasi latihan.

\section{Metode}

Kegiatan pengabdian ini dilaksanakan pada tanggal 22-24 Juli 2021. Dengan menggunakan pendekatan pelatihan dan pendampingan secara langsung, kegiatan pengabdian kepada masyarakat ini ditujukan untuk siswa/i tingkat Madrasah Ibtidaiyah Delegtukang, Kecamatan Wiradesa, Kabupaten Pekalongan. Kegiatan ini fokus pada memberikan edukasi dan pelatihan jenis-jenis latihan kebugaran jasmani berbasis senam koreografi yang dapat dilakukan secara mandiri dirumah sehingga level kebugaran jasmani sebagai implikasi dari latihan kebugaran yang diberikan tidak diukur saat kegiatan pelatihan ini.

Adapun detail uraian program kegiatan pengabdian secara umum dapat diperhatikan seperti pada tabel berikut:

Tabel 2.1 Uraian program kegiatan pengabdian

\begin{tabular}{|c|c|c|c|}
\hline No & Program Kerja & Uraian Pelaksanaan & Ketercapaian \\
\hline 1 & $\begin{array}{l}\text { Penjelasan materi } \\
\text { pentingnya } \\
\text { pemeliharaan } \\
\text { kebugaran jasmani } \\
\text { dimasa pandemi } \\
\text { covid -19 }\end{array}$ & $\begin{array}{l}\text { Tim pengabdi memberikan } \\
\text { pemahaman secara konsep dengan } \\
\text { cara menjelaskan pentingnya } \\
\text { pemeliharaan kebugaran jasmani di } \\
\text { masa pandemi covid-19. }\end{array}$ & $\begin{array}{l}\text { Siswa/i memahami } \\
\text { pentingnya pemeliharaan } \\
\text { kebugaran jasmani di } \\
\text { masa pandemi covid }-19 \text {. }\end{array}$ \\
\hline 2 & $\begin{array}{lr}\text { Penjelasan } & \text { materi } \\
\text { mengenai } & \text { prinsip- } \\
\text { prinsip } & \text { latihan } \\
\text { kebugaran } & \text { jasmani } \\
\text { yang } & \text { meliputi; } \\
\text { bentuk } & \text { latihan, } \\
\text { tujuan dan } & \text { sasaran } \\
\text { latihan } & \end{array}$ & $\begin{array}{l}\text { Tim pengabdi memberikan } \\
\text { pemahaman secara konsep dengan } \\
\text { cara menjelaskan prinsip-prinsip } \\
\text { latihan kebugaran jasmani yang } \\
\text { meliputi; bentuk latihan, tujuan dan } \\
\text { sasaran latihan, intensitas latihan, } \\
\text { frekuensi latihan, serta durasi latihan }\end{array}$ & $\begin{array}{l}\text { Siswa /i memahami } \\
\text { dengan baik prinsipprinsip } \\
\text { latihan kebugaran } \\
\text { jasmani yang meliputi; } \\
\text { bentuk latihan, tujuan } \\
\text { dan sasaran latihan. }\end{array}$ \\
\hline 3 & $\begin{array}{l}\text { Pendampingan } \\
\text { kegiatan latihan } \\
\text { kebugaran jasmani }\end{array}$ & $\begin{array}{l}\text { Tim pengabdi } \text { memberikan } \\
\text { pendampingan latihan kebugaran } \\
\text { jasmani secara langsung kepada } \\
\text { siswa/i }\end{array}$ & $\begin{array}{l}\text { Siswa melakukan latihan } \\
\text { kebugaran jasmani } \\
\text { dengan keterampilan } \\
\text { gerak yang baik. }\end{array}$ \\
\hline
\end{tabular}

\section{Hasil dan Pembahasan}

Hasil

Kegiatan pengabdian ini dilaksanakan di Madrasah Ibtidaiyah Delegtukang, Kecamatan Wiradesa, Kabupaten Pekalongan pada tanggal 22-24 Juli 2021. Seluruh rangkaian kegiatan pengabdian ini dilakukan di ruang terbuka yakni di lapangan 


\section{Prosiding Seminar Nasional Kesehatan Lembaga Penelitian dan Pengabdian Masyarakat Universitas Muhammadiyah Pekajangan Pekalongan

sepakbola Desa Naruwolo. Siswa/i yang terlibat dalam kegiatan pelatihan ini secara keseluruhan berjumlah 74 siswa dengan pembagian satu kelas setiap harinya, kurang lebih 25 siswa yang terlibat. Dengan metode ceramah dan praktikkum, seluruh peserta kegiatan dilibatkan secara langsung dalam setiap rangkaian kegiatan yakni mulai dari sesi penjelasan materi hingga sesi praktik latihan kebugaran jasmani. Seluruh kegiatan pengabdian dilakukan dengan tetap memperhatikan protokol kesehatan terkait covid19 seperti mencuci tangan, memakai masker dan menjaga jarak sehingga dipastikan kegiatan pengabdian ini tidak menimbulkan resiko penularan covid-19. Rangkaian kegiatan pelatihan yang dilakukan adalah sebagai berikut:

Tabel 3.2 Kegiatan pelatihan program olahraga Kesehatan

\begin{tabular}{|c|c|c|}
\hline No & Materi Kegiatan & Hasil \\
\hline 1 & $\begin{array}{ll}\text { Penjelasan } & \text { materi } \\
\text { pentingnya } & \\
\text { pemeliharaan } & \\
\text { kebugaran jasmani } \\
\text { dimasa } & \text { pandemi } \\
\text { covid -19 } & \end{array}$ & $\begin{array}{l}\text { Kegiatan ini diawali dengan penjelasan materi pentingnya } \\
\text { pemeliharaan kebugaran jasmani di masa pandemi COVID-19 } \\
\text { oleh tim pengabdi dan dilanjutkan dengan sesi diskusi. Setiap } \\
\text { peserta terlibat aktif dalam kegiatan diskusi. Tim pengabdi } \\
\text { memberikan pertanyaan-pertanyaan stimulasi seputar isu } \\
\text { pemeliharaan kebugaran jasmani untuk memacu peserta } \\
\text { memahami dan mendalami materi. }\end{array}$ \\
\hline 2 & $\begin{array}{lr}\text { Penjelasan } & \text { materi } \\
\text { mengenai } & \text { prinsip- } \\
\text { prinsip } & \text { latihan } \\
\text { kebugaran } & \text { jasmani } \\
\text { yang } & \text { meliputi; } \\
\text { bentuk } & \text { latihan, } \\
\text { tujuan dan } & \text { sasaran } \\
\text { latihan } & \end{array}$ & $\begin{array}{l}\text { Tim pengabdi menjelaskan secara detail tentang prinsip-prinsip } \\
\text { latihan kebugaran jasmani. Setiap peserta dilibatkan secara } \\
\text { langsung selama sesi diskusi. Tim pengabdi memaparkan } \\
\text { substansi materi tentang prinsip latihan kebugaran jasmani yang } \\
\text { meliputi; variasi bentuk latihan kebugaran jasmani dengan } \\
\text { pendekatan training, sasaran dan tujuan, bagi pelajar usia } \\
\text { madrasah. }\end{array}$ \\
\hline 3 & $\begin{array}{l}\text { Pendampingan } \\
\text { kegiatan latihan } \\
\text { kebugaran jasmani }\end{array}$ & $\begin{array}{l}\text { a. Tim pengabdi terlibat langsung dalam memberikan contoh } \\
\text { tiapgerakkan latihan kebugaran jasmani. } \\
\text { b. Mengarahkan peserta kegiatan untuk melakukan } \\
\text { teknikgerakan latihan kebugaran jasmani secara maksimal. } \\
\text { c. Melakukan pendampingan kepada masing-masing peserta } \\
\text { saat melakukan kegiatan latihan kebugaran jasmani. } \\
\text { d. Memperbaiki kesalahan peserta kegiatan terkait dengan } \\
\text { teknik dasar gerak latihan senam. } \\
\text { e. Memotivasi peserta kegiatan agar dapat melakukan latihan } \\
\text { mandiri di rumah masing-masing secara teratur dan } \\
\text { berkelanjutan. } \\
\text { f. Mengarahkan peserta kegiatan untuk melakukan gerakan } \\
\text { g. Aktivitas senam sesuai dengan menu latihan yang telah } \\
\text { disediakan tim pengabdi meliputi bentuk latihan, dalam } \\
\text { rangka menunjang pemeliharaan kebugaran jasmani di masa } \\
\text { pandemi covid-19. } \\
\text { h. Mengarahkan peserta kegiatan untuk mengevaluasi } \\
\text { kemampuan gerak fisik masing-masing untuk selanjutnya } \\
\text { dapat dijadikan acuan dalam menetapkan program latihan } \\
\text { kebugaran jasmani secara mandiri di rumah masing-masing. }\end{array}$ \\
\hline
\end{tabular}

Adapun program olahraga kesehatan yang diberikan kepada para peserta dalam kegiatan pengabdian kepada masyarakat ini adalah latihan kebugaran jasmani melalui aktivitas koreograsi senam imaji dapat dilihat pada tabel program latihan berikut: 


\section{Prosiding Seminar Nasional Kesehatan Lembaga Penelitian dan Pengabdian Masyarakat Universitas Muhammadiyah Pekajangan Pekalongan

Tabel 3. Program latihan kebugaran jasmani melalui senam imaji

\begin{tabular}{|c|c|c|c|}
\hline No & $\begin{array}{l}\text { Tahapan } \\
\text { Latihan }\end{array}$ & Jenis Gerakan & Manfaat Gerakan \\
\hline 1 & Peregangan & adaptasi jurus Tapak Suci dan IPSI & $\begin{array}{l}\text { Mengurangi risiko cedera, } \\
\text { fleksibiltas otot }\end{array}$ \\
\hline 2 & Pemansan & adaptasi gerak 3M, wudhu dan sholat & $\begin{array}{l}\text { Mengurangi risiko cedera, } \\
\text { fleksibiltas otot }\end{array}$ \\
\hline \multirow[t]{3}{*}{3} & Inti & $\begin{array}{l}\text { Inti } 1 \text { : } \\
\text { - adaptasi gerakan olahraga renang } \\
\text { dan mecuci tangan } \\
\text { - adaptasi gerakan takbir sholat dan } \\
\text { gerakan memanah }\end{array}$ & $\begin{array}{l}\text { Kekuatan, daya tahan, dan } \\
\text { kelentukan Otot bahu dan otot } \\
\text { hamstring }\end{array}$ \\
\hline & & $\begin{array}{l}\text { Inti 2: } \\
\text { - } \text { adaptasi gerakan menggunakan } \\
\text { masker dan memanah } \\
\text { - adaptasi gerakan mencuci tangan } \\
\text { dan berenang }\end{array}$ & $\begin{array}{l}\text { Gerak motorik kasar, } \\
\text { Kekuatan, daya tahan, dan } \\
\text { kelentukan otot bahu, dan } \\
\text { koordinasi }\end{array}$ \\
\hline & & $\begin{array}{l}\text { Inti 3: } \\
\text { - } \quad \text { adaptasi gerakan menggunakan } \\
\text { masker dan memanah } \\
\text { - } \quad \text { adaptasi berkuda dan menjaga jarak }\end{array}$ & $\begin{array}{lll}\text { Kekuatan, daya } & \text { tahan, dan } \\
\text { kelentukan otot bahu, otot } \\
\text { gastrocnemius, dan otot } \\
\text { hamstring }\end{array}$ \\
\hline 4 & pendinginan & adaptasi jurus Tapak Suci dan IPSI & $\begin{array}{l}\text { Mengurangi kelelahan otot, } \\
\text { fleksibilitas otot }\end{array}$ \\
\hline
\end{tabular}

\section{Pembahasan}

Berdasarkan dengan hasil evaluasi kegiatan pengabdian yang dilakukan, dapat disimpulkan beberapa hal sebagai berikut:

1. Secara umum, kegiatan pengabdian memberikan dampak yang baik bagi para peserta kegiatan (siswa/i madrasah) dalam aspek pemahaman akan pentingnya pemeliharaan kebugaran jasmani di masa pandemi covid-19 melalui program olahraga kesehatan. Para peserta kegiatan antuasias dan proaktif mengikuti semua item kegiatan pengabdian mulai dari awal hingga akhir baik pada sesi diskusi maupun praktik latihan kebugaran.

2. Adanya peningkatan keterampilan gerak para peserta kegiatan yakni gerak latihan kebugaran jasmani dengan melelui aktivitas koreografi senam imaji. Setelah mengikuti beberapa tahapan simulasi dan latihan kebugaran jasmani, para peserta memiliki keterampilan gerak yang baik. Latihan yang dilakukan secara bertahap dan berulang-ulang mulai dari gerakan pemanasan, gerakan inti hingga pendinginan dapat dilakukan dengan baik oleh semua peserta.

3. Peserta kegiatan mengharapkan keberlanjutan prpogram-program pengabdian sejenis yang dapat memberikan manfaat secara langsung bagi aspek pemeliharaan kesehatan dan kebugaran fisik selama masa pandemi covid-19.

Penyelenggaraan kegiatan pelatihan program olahraga kesehatan untuk pemeliharaan kebugaran jasmani ini memberikan dampak yang baik bagi perubahan pola pikir pelajar mengenai pentingnya upaya-upaya pemeliharaan kebugaran jasmani masa pandemi covid-19 melalui program-program latihan olahraga kesehatan. Pendampingan yang dilakukan secara langsung selama kegiatan pengabdian perlu 


\section{Prosiding Seminar Nasional Kesehatan Lembaga Penelitian dan Pengabdian Masyarakat Universitas Muhammadiyah Pekajangan Pekalongan

dilakukan secara teratur dan bersifat kontinyu sehingga dapat memberikan manfaat yang baik tidak hanya menyangkut peningkatan pola pemahaman pelajar tentang urgensi pemeliharaan status kebugaran fisik selama masa pandemi covid-19 tetapi lebih dari itu dapat membiasakan mereka untuk rutin melatih keterampilan gerak fisik melalui latihanlatihan olahraga kesehatan yang adekuat dengan pengaturan intensitas, durasi, serta frekuensi latihan yang disesuaikan dengan kemampuan fisik masingmasing [3]. Pendekatan latihan kebugaran jasmani melalui kegiata ini secara teknis dapat dilakukan secara mandiri di rumah tanpa harus menggunakan alat bantu latihan yang mahal namun dapat memberikan manfaat yang baik untuk tujuan pemeliharaan kebugaran jasmani [3]. Dengan memanfaatkan tubuh sendiri, pelajar dapat melakukan berbagai variasi bentuk gerak latihan untuk tujuan pemeliharaan kebugaran fisik agar tetap dalam keadaan optimal. Selain menunjang kebugaran fisik yang optimal, latihan kebugaran jasmani yang dilakukan secara teratur dan bersifat kontinyu juga dapat memberikan manfaat yang baik bagi peningkatan kinerja kognitif seseorang [13]. Pelatihan dan pendampingan yang dilakukan ini berfokus pada menstimulasi pola pikir pelajar SMA agar dapat memiliki pemahaman yang baik mengenai pentingnya melakukan berbagai upaya pemeliharaan kebugaran jasmani selama masa pandemi covid-19 melalui berbagai bentuk kegiatan latihan kebugaran jasmani yang mudah dilakukan secara mandiri di rumah masing-masing tanpa harus melibatkan banyak orang. Lebih dari itu, pendampingan yang diberikan secara langsung selama kegiatan pelatihan, dititikberatkan pada tujuan untuk merangsang respon gerak fisik para pelajar agar terbiasa dengan berbagai variasi latihan kebugaran fisik melalui aktivitas koreografi senam imaji. Hal ini bertujuan agar para siswa memiliki keterampilan gerak fisik yang baik dan memadai agar dapat menunjang segala bentuk kebutuhan kinerja fisik sehari-hari di rumah selama masa pandemi covid-19.

\section{Kesimpulan}

Beberapa hal yang dapat disimpulkan dari kegiatan pengabdian ini adalah; penyelenggaraan kegiatan pengabdian dengan pendekatan pendampingan program olahraga kesehatan bagi pelajar perlu untuk dilakukan agar dapat memberikan manfaat lebih bagi para siswa di masa pandemi covid-19. Melalui kegiatan pelatihan kebugaran jasmani, siswa distimulasi untuk selalu menerapkan pola hidup aktif dan sehat selama pandemi covid-19 yakni dengan menerapkan protokol kesehatan terkait covid-19 serta rutin menjalankan program latihan olahraga kesehatan yang dapat dilakukan secara mandiri di rumah masing-masing. Adapun jenis latihan yang direkomendasikan untuk dapat dilakukan dirumah adalah senam imaji. Dengan kegiatan pelatihan yang dilakukan, para peserta memperoleh pemahaman serta keterampilan gerak yang baik berkaitan dengan upaya pemeliharaan kebugaran fisik selama pandemi covid-19 melalui latihan olahraga kesehatan.

\section{Referensi}

[1] Abduljabar, B. (2011). Pengertian pendidikan jasmani. Ilmu Pendidikan.

[2] Bachmann, J. M., DeFina, L. F., Franzini, L., Gao, A., Leonard, D. S., Cooper, K. H., Berry, J. D., \& Willis, B. L. (2015). Cardiorespiratory Fitness in Middle Age and Health Care Costs in Later Life. Journal of the American College of Cardiology, 66(17), 1876-1885. https://doi.org/10.1016/j.jacc.2015.08.030. 


\section{Prosiding Seminar Nasional Kesehatan \\ Lembaga Penelitian dan Pengabdian Masyarakat Universitas Muhammadiyah Pekajangan Pekalongan}

[3] Bile, R. L., \& Suharjana. (2019). Efektivitas Penggunaan Model Latihan Kebugaran " BBC Exercise " Untuk Pemeliharaan Kebugaran Jasmani Mahasiswa. SPORTIVE : Journal of Physical Education , Sport and Recreation, 3(September), 30-37.

[4] Hale, R., Green, J., Hausselle, J., Saxby, D., \& Gonzalez, R. V. (2018). Quantified in vitro tibiofemoral contact during bodyweight back squats. Journal of Biomechanics, 79, 21-30. https://doi.org/10.1016/j.jbiomech.2018.07.002.

[5] Irianto, Djoko Pekik. (2017). Gizi Keluarga dan Olahragawan. 106-109.

[6] Kim, J. K., Son, W. Il, Sim, Y. J., Lee, J. S., \& Saud, K. O. (2020). The study of health-related fitness normative scores for nepalese older adults. International Journal of Environmental Research and Public Health, 17(8), 1-15. https://doi.org/10.3390/ijerph17082723

[7] Kim, J. K., Son, W. Il, Sim, Y. J., Lee, J. S., \& Saud, K. O. (2020). The study of health-related fitness normative scores for nepalese older adults. International Journal of Environmental Research and Public Health, 17(8), 1-15. https://doi.org/10.3390/ijerph17082723.

[8] Knaeps, S., Bourgois, J. G., Charlier, R., Mertens, E., Lefevre, J., \& Wijndaele, K. (2016). Ten-year change in sedentary behaviour, moderate- to-vigorous physical activity, cardiorespiratory fitness and cardiometabolic risk: independent associations and mediation analysis. British Journal of Sports Medicine, 0 (August), 1-7. https://doi.org/10.1136/bjsports-2016-096083

[9] Knaeps, S., Bourgois, J. G., Charlier, R., Mertens, E., Lefevre, J., \& Wijndaele, K. (2016). Ten-year change in sedentary behaviour, moderate- to-vigorous physical activity, cardiorespiratory fitness and cardiometabolic risk: independent associations and mediation analysis. British Journal of Sports Medicine, 0 (August), 1-7. https://doi.org/10.1136/bjsports-2016-096083

[10] Lipecki, K., \& Rutowicz, B. (2015). The impact of ten weeks of bodyweight training on the level of physical fitness and selected parameters of body composition in women aged 21-23 years. Pol. J. Sport Tourism 2015, 22, 64-73.

[11] Lipecki, K., \& Rutowicz, B. (2015). The impact of ten weeks of bodyweight training on the level of physical fitness and selected parameters of body composition in women aged 21-23 years. Pol. J. Sport Tourism 2015, 22, 64-73.

[12] Panggarita, Gilang Nuari. (2020). Profil Tingkat Kebugaran Jasmani Mahasiswa Program Studi Pendidikan Olahraga. JO: Jendela Olahraga. Volume 05, No. 2 (Juli) 27-33.

[13] Ruotsalainen, I., Gorbach, T., Perkola, J., Renvall, V., Syväoja, H. J., Tammelin, T. H., Karvanen, J., \& Parviainen, T. (2020). Physical activity, aerobic fitness, and brain white matter: Their role for executive functions in adolescence. Developmental Cognitive Neuroscience, 42. https://doi.org/10.1016/j.dcn.2020.100765

[14] Tapo, Y. B. O., \& Bile, R. L. (2020). Efektivitas penggunaan model latihan olahraga pernapasan MONACORS untuk pemeliharaan kesehatan fungsi paru bagi mahasiswa dalam menghadapi pandemi COVID-19. Ejurnal IMEDTECH, $4(2), 54-65$. 